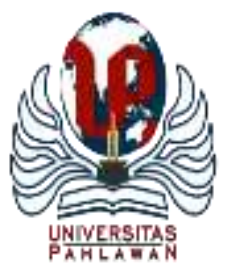

Edukatif : Jurnal Ilmu Pendidikan Volume 3 Nomor 6 Tahun 2021 Halm 5085 - 5091

EDUKATIF: JURNAL ILMU PENDIDIKAN

Research \& Learning in Education

https://edukatif.org/index.php/edukatif/index

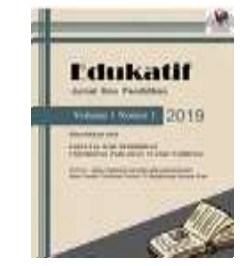

\title{
Strategi Pengembangan Karakter Entrepreneurship di Sekolah
}

\author{
Helty Asafri ${ }^{1 凶}$, Pitriyani $^{2}$, Rosmiati $^{3}$
}

Universitas Jambi, Indonesia ${ }^{1,2,3}$

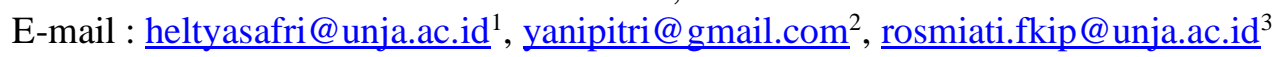

\begin{abstract}
Abstrak
Latar belakang penelitian yaitu untuk mengetahui strategi pengembangan karakter entrepreneurship di sekolah. Tujuan dari penulisan yaitu untuk mendeskripsikan konsep dasar Pendidikan karakter dan mendeskripsikan peran Pendidikan karakter sebagai strategi dalam membentuk karakter entrepreneurship di sekolah. Metode penelitian ini adalah penelitian studi literatur. Hasil dan Pembahasan penelitian yaitu strategi yang dilakukan untuk menanamkan karakter kewirausahaan pada anak di sekolah dengan mengadakan kegiatan program cooking class (kelas memasak), program outing class (melaksanakan kelas diluar ruangan), dan program market day (kegiatan berjualan). Program kegiatan ini bebas dilakukan kapan saja dan dengan intensitas yang tinggi maupun rendah disesuaikan dengan kondisi dan situasi lingkungan maupun anak sebagai pemeran utamanya. Pada tingkat menengah atas strategi kegiatan akan dibuat lebih kompleks. SMK sebagai sekolah dengan keahlian khusus sudah lebih dulu mengimplementasikan strategi ini, bahkan pengintegrasian nilai kewirausahaan kedalam mata pelajaran sudah sejak awal dilakukan.
\end{abstract}

Kata Kunci: Pengembangan Karakter Enterpreneurship

\begin{abstract}
The background of the research is to determine the strategy of developing entrepreneurship character in schools. The purpose of writing is to describe the basic concepts of character education and describe the role of character education as a strategy in shaping the character of entrepreneurship in schools. This research method is literature study research. The results and discussion of the research are strategies that are carried out to instill entrepreneurial character in children at school by holding cooking class program activities (cooking classes), outing class programs (implementing outdoor classes), and market day programs (selling activities). This program of activities is free to be carried out at any time and with high or low intensity adjusted to the conditions and situations of the environment and children as the main actors. At the upper secondary level the strategy of activities will be made more complex. Vocational Schools as schools with special skills have already implemented this strategy, even integrating entrepreneurial values into subjects has been carried out since the beginning.
\end{abstract}

Keywords: Entrepreneurship Character Development

Copyright (c) 2021 Helty Asafri, Pitriyani, Rosmiati

$\triangle$ Corresponding author:

Email : yanipitri@gmail.com

DOI : https://doi.org/10.31004/edukatif.v3i6.1588

ISSN 2656-8063 (Media Cetak)

ISSN 2656-8071 (Media Online)

Edukatif : Jurnal Ilmu Pendidikan Vol 3 No 6 Tahun 2021 p-ISSN 2656-8063 e-ISSN 2656-8071 


\section{PENDAHULUAN}

Memasuki era revolusi industri 4.0 saat ini tidak jarang kita akan menemukan anak-anak yang sudah dididik untuk berkompetisi sedari kecil karena persaingan hidup yang semakin ketat di setiap tahunnya. Setiap manusia harus memiliki nilai jual tinggi dan skill yang mumpuni supaya bisa menghadapi persaingan yang ketat di beberapa tahun ke depannya (Madjid, 2011). Oleh karena itu, sangat penting untuk menanamkan dan melakukan pengembangan karakter entrepreneurship pada anak mulai dari lingkungan keluarga dan juga di sekolah. Pendidikan sebagai usaha membina dan mengembangkan pribadi manusia dari aspek-aspek rohaniah dan jasmaniah juga harus berlangsung secara bertahab, oleh karena suatu kematangan yang bertitik akhir pada optimalisasi perkembanga atau pertumbuhan, baru dapat tercapai bilamana berlangsung melalui proses demi proses kearah tujuan akhir perkembangan atau pertumbuhan (Engkoswara, 2011)

Salah satu alasan utama mengapa perlu adanya pengembangan Pendidikan karakter entrepreneurship pada anak usia sekolah karena dapat melatih anak menjadi lebih kreatif dan mandiri, sekaligus mempersiapkan anak sebagai pribadi yang memliki daya juang tinggi dan daya saing yang mumpuni. Pendidikan merupakan satu cara paling efektif untuk mebentuk karakter seseorang, sesuai definisinya pendidikan adalah upaya sadar dan terencana dalam proses pembimbingan dan pembelajaran bagi individu agar tumbuh kembang menjadi manusia yang mandiri, bertanggungjawab, kreatif, berilmu, sehat dan berakhlak (berkarakter) mulia (Koesuma, 2010). Potensi manusia berupa akal sehat digunakan untuk berfikir, bernalar dan menganalisa suatu permasalahan hidup tentunya membuat manusia untuk menemukan suatu solusi yang tepat dalam meyelesaikan permasalahannya (Qolb \& Hamami, 2021).

Adapun Persamaan dan perbedaan dengan penelitian terdahulu yaitu penelitian yang dilakukan (Rasul, 2013) tentang Pelaksanaan Pendidikan Karakter, Ekonomi Kreatif, Dan Kewirausahaan Dalam Belajar Aktif di SMK bahwa persamaannya terletak pada pembahasan tentang pelaksanaan pendidikan karakter yang dilakukan di SMK. Sedangkan perbedaannya yaitu terletak pada pembahasan ekonomi kreatif, adapun penelitian ini tidak membahas tentang ekonomi kreatif.

Pada penelitan yang dilakukan (Afandi, 2019) tentang Strategi Pendidikan Entrepreneurship di Pesantren Al Mawaddah Kudus persamaannya terletak pada pembahasan tentang strategi pendidikan enterpreunirship perbedaannya yaitu pada tempat penelitian di pesantren Al Mawaddah Kudus sedangkan pada penelitian ini membahas pada sekolah dasar dan SMK.

Selanjutnya persamaan dari penelitian yang dilakukan (Yanti \& Mauliza, 2021) tentang sterategi mengembangkan jiwa entrepreneur kepada siswa Sekolah Menegah Pertama (SMP) yaitu terletak pada pembahasan strategi mengembangkan jiwa entrepreneur pada siswa dan perbedaannya terletak pada tempatnya di Sekolah Menengah Pertama (SMP) sedangkan pada penelitian ini membahas di sekolah dasar dan SMK.

\section{METODE PENELITIAN}

Metode penelitian ini adalah penelitian studi literatur. Menurut (Dantes \& Nyoman, 2012) metode penelitian studi literatur adalah sebagai serangkaian kegiatan yang berkenaan dengan metode pengumpulan data pustaka, membaca dan mencatat, serta mengelolah bahan penelitian. Jenis data yang dikumpulkan berupa data sekunder berupa hasil penelitian dari berbagai artikel, sumber pustaka dan dokumen yang sesuai dengan tema. Penerapan dalam studi literatur ini dibagi menjadi beberapa tahapan : 1. Menentukan topik dan konsentrasi yang akan menjadi fokus penelitian sehingga dapat merumuskan judul penelitan. Selain itu peneliti mendeskripsikan urgensi dan novelty topik penelitan yang akan diteliti. Selanjutnya peneliti dapat merumuskan masalah dan tujuan yang ingin dicapai 2. Melakukan proses pencarian kepustakaan dengan menggunakan kata kunci yang relevan dengan variabel topik penelitian. Literatur dapat dicari melalui berbagai sumber yang tersedia secara cetak maupun elektronik. Setelah literatur terkumpul, kemudian dilakukan proses analisis. Pengumpulan literatur ini dilakukan sejak Oktober 2021. Pencarian menggunakan 
Google Cendekia. Adapun artikel yang digunakan dalam penelitian ini berjumlah 3 artikel. Pertama artikel atas nama Zaenal Afandi tentang Strategi Pendidikan Entrepreneurship di Pesantren Al Mawaddah Kudus diterbitkan pada jurnal BISNIS: Jurnal Bisnis dan Manajemen Islam P-ISSN: 2442-3718, E-ISSN: 2477-5533 Volume 7, Nomor 1, Juni 2019. Kedua, artikel atas nama Djuharis Rasul tentang Pelaksanaan Pendidikan Karakter, Ekonomi Kreatif, Dan Kewirausahaan Dalam Belajar Aktif di SMK diterbitkan pada jurnal Pendidikan dan Kebudayaan, Vol. 19, Nomor 1, Maret 2013. Ketiga, artikel atas nama Aprilda Yanti dan Putri Mauliza tentang Sterategi Mengembangkan Jiwa Entrepreneur Kepada Siswa Sekolah Menegah Pertama (SMP) diterbitkan pada jurnal INFORMATIKA Manajemen Informatika Universitas Labuhanbatu Vol. 9 No. 3 / September /2021 2615-1855 (E-ISSN) 2303-2863 (P-ISSN).

\section{HASIL DAN PEMBAHSAN PENELITIAN}

\section{Pendidikan Karakter Sebagai Strategi Pembentuk Karakter Entrepreneurship di Sekolah}

Menurut Fathul muin (Koesuma, 2010) kata karakter diambil dari bahasa Inggris dan juga bersal dari bahasa Yunani Character. Kata ini awalnya digunakan untuk menandai hal yang mengesankan dari dua koin (keping uang). Dalam kamus Poerwadarminta, karakter diartikan sebagai tabiat, watak, sifat-sifat kejiwaan, akhlak atau budi pekerti yang membedakan seseorang dengan yang lain. Karakter cenderung disamakan dengan personalitas atau kepribadian. Orang yang memiliki karakter berarti memiliki kepribadian. Keduanya diartikan sebagai totalitas nilai yang dimiliki seseorang yang mengarahkan manusia dalam menjalani kehidupannya. Totalitas nilai meliputi tabiat, akhlak, budi pekerti dan sifat-sifat kejiawaan lainya (Basuki, 2007).

Hal senada disampaikan (Rasul, 2013) Ada dua makna yang terkandung dalam istilah "Pendidikan Karakter", yaitu pendidikan dan karakter. Pendidikan adalah suatu usaha sadar dan sistematis dalam mengembangkan potensi peserta didik dalam rangka mempersiapkan generasi muda untuk mencapai masyarakat dan bangsa yang lebih baik di masa depan. Usaha sadar dan sistematis tersebut perlu dilaksanakan dalam bentuk terencana dengan baik untuk mengembangkan potensi peserta didik, sehingga memiliki sistem/pola berpikir, nilai, moral, dan keyakinan yang sesuai dengan kehidupan masa kini dan masa mendatang. Adapun karakter digambarkan sebagai sifat manusia yang banyak tergantung dari faktor pengalaman hidupnya sendiri.

Makna yang sama juga disampaikan (Afandi, 2019) bahwa Kewirausahaan (entrepreneurship) juga dikatakan sebagai suatu sikap, jiwa dan kemampuan untuk menciptakan sesuatu yang baru, yang sangat bernilai dan berguna baik bagi dirinya sendiri maupun bagi orang lain. Kewirausahaan ini merupakan sikap mental dan jiwa yang selalu aktif atau kreatif, berdaya, pencipta, berkarya, sersahaja dan berusaha dalam rangka meningkatkan pendapatan atas kegiatan usahanya. hal ini selaras dengan penelitian yang dilakukan Hani \& Rokhmani (Yanti \& Mauliza, 2021) beberapa strategi menumbuhkan jiwa entrepreneur siswa yaitu : 1. Pengoptimalan pengetahuan kewirausahaan yang dimiliki siswa harus ditingkatkan dengan berkonsentrasi pada mata pelajaran kewirausahaan. Sehingga siswa memiliki pengetahuan kewirausahaan lebih maksimal serta senantiasa akan terwujud pembelajaran kewirausahaan yang baik dan maksimal; 2. Dengan adanya jiwa wirausaha yang dimiliki oleh siswa diharapkan siswa dapat memanfaatkan jiwa wirausaha tersebut serta mengatasi kendala yang ada dalam menjalankan usaha. Sehingga terwujud kelancaran dan kemudahan dalam pelaksanaan kegiatan kewirausahaan.

Amanat Undang-Undang dan Kebijakan Nasional Pendidikan UU Sisdiknas, Nawacita, Trisakti, RPJMN 2015-2019, Amanat Presiden RI, Kebijakan Kemendikbud Fokus pada Pendidikan Karakter Pendidikan karakter bukan produk baru, bukan mata pelajaran, bukan kurikulum baru tetapi merupakan penguatan atau fokus dari proses pembelajaran dan sebagai poros atau ruh atau jiwa Pendidikan (Mulyani \& dkk, 2010) 
Berawal dari program rencana kerja pasangan presiden dan wakil presiden Jokowi dan Jusuf Kala yang bernama Nawacita, terbentuklah suatu program besar yang di kenal dengan sebutan Penguatan Pendidikan Karakter (PPK). Program ini merupakan kebijakan Pendidikan nasional yang bertujuan:

1. Membangun dan membekali Peserta Didik sebagai generasi emas Indonesia Tahun 2045 guna menghadapi dinamika perubahan di masa depan;

2. Mengembangkan platform pendidikan nasional yang meletakkan pendidikan karakter sebagai jiwa utama dengan memperhatikan keberagaman budaya Indonesia;

3. Merevitalisasi dan memperkuat potensi dan kompetensi ekosistem pendidikan. Kualitas karakter merupakan salah satu aspek untuk membangun Generasi Emas 2045, disertai kemampuan dalam aspek literasi dasar dan kompetensi abad 21.

a. Berikut ini merupakan keterampilan abad 21 yang dibutuhkan setiap siswa:

4. Kualitas Karakter: Religiositas, nasionalisme, kemandirian, gotong royong, dan integritas.

5. LIterasi Dasar: Literasi Bahasa, literasi numerasi, literasi sains, literasi digital (teknologi informasi \& komunikasi), literasi finansial, literasi budaya dan kewargaan.

6. Kompetensi: berpikir kritis, kreativitas, komunikasi, dan kolaborasi. Arah kebijakan pembangunan pendidikan nasional diatas dimaksudkan untuk menerapkan strategi pendidikan akhlak mulia dan karakter bangsa termasuk karakter wirausaha.

Kesimpulan yang bisa diambil dari beberapa pemahaman peneliti yang bersumber dari artikel tentang pendidikan karakter sebagai strategi pembentuk karakter entrepreneurship di sekolah bahwa seluruh kebijakan pengembangan karakter sebaiknya mengakar pada budaya bangsa. Semakin mengakar kebijakan tersebut maka akan semakin kuat pula kecenderungan peserta didik untuk tumbuh dan berkembang menjadi warga negara yang baik. Dengan demikian, fungsi Pendidikan Karakter yaitu membentuk dan mengembangkan potensi manusia atau warga negara Indonesia agar berpikiran baik, berhati baik, dan berperilaku baik sesuai dengan falsafah hidup Pancasila.

\section{Strategi Pengembangan karakter Entrepreneurship di Sekolah Dasar}

Strategi Pengembangan karakter Entrepreneurship di Sekolah Dasar Pembentukan keperibadian kewirausahaan dimulai sejak dalam kandungan, melalui pola hidup, pola makan, dan tingkah laku orang tuanya. Semua pengalaman yang dilalui panca indranya, akan terserap dan masuk sebagai unsur kepribadian dalam proses perkembangannya. Sebelum masuk sekolah, anak telah banyak dibekali pengalaman dan pengetahuan yang diterimanya dirumah, baik itu dari orang tua, saudara, anggota keluarganya, sampai dengan teman sepermainannya (Mulyani \& Jamilus, 2021).

Pendidikan moral termasuk jiwa kewirausahaan yang harus ditanamkan mulai sejak masih balita dengan cara mulai membiasakan anak-anak untuk mematuhi peraturan yang baik, benar, jujur dan adil. Menurut Donal Kurtopo (Basuki, 2007), kewirausahaan sebenarnya sudah dipelajari setiap individu, yang dari kecil sudah dibekali benih-benih wirausaha. Pendidikan kewirausahaan merupakan pendidikan nilai yang mengarahkan berkembangnya keperibadian wirausaha. Nilai-nilai kewirausahaan antara lain; kreativitas, keberanian, keuletan, kejujuran, kerja keras, orientasi masa depan, dorongan berprestasi tinggi, disiplin, kemandirian, iman dan taqwa.

Karakteristik wirausahawan menurut Pickle dan Abrahamson (Saputro, Achmad,, \& Handayani, 2016) adalah meotivasi untuk maju, kekuatan mental, kemampuan menjalani hubungan antar manusia, kemampuan berkomunikasi, pengetahuan teknis, kemampuan mengaplikasikan, kemampuan menelaah, memandang ke depan, kemampuan menghitung, kemampuan berorganisasi, memiliki keberanian, keteladanan, memahami arti tanggung jawab dan kehormatan inovatif , berpartisipasi, pandai membaca situasi, memanfaatkan waktu secara efisien, memiliki sikap mental positif kepada pekerjaan.

Menurut McClelland (Koesuma, 2010) seorang entrepreneur memiliki virus mental positif, yang mendorongnya untuk berpikir dan berbuat maju dalam melakukan sesuatu. Virus mental entrepreneur menunjukan adanya kemauan keras meraih tujuan, keyakinan, kepercayaan pada kemampuan diri sendiri 
bermotif prestasi, memiliki tanggung jawab kejujuran dan tanggung jawab kekuatan fisik, mental, sabar, tabah, kerja keras dan energik. Sebagai salah satu implementasi paradigma baru pendidikan, istilah keterampilan kecakapan hidup (life skill) adalah kecakapan yang dimiliki seseorang untuk mau dan berani menghadapi problema hidup dan kehidupan secara wajar tanpa merasa tertekan, kemudian secara proaktif dan kreatif mencari dan menemukan solusi sehingga akhirnya mampu mengatasinya.

Usaha perubahan ini bermuara pada satu tujuan, yaitu tercapainya peningkatan mutu hasil pendidikan yang pada akhirnya dapat meningkatkan mutu dan taraf hidup masyarakat dan bangsa. Semakin Life Skillin meningkatnya kesadaran orang tua memasukan anaknya pada lembaga- lemabaga pendidikan prasekolah. Misalnya berkembangnya tempat-tempat penitipan anak, kelompok bermain (play group), taman kanak-kanak, baik regular maupun terpadu yang umumnya dikelola oleh masyarakat. Hal ini sangat beralasan, dikarenakan diera sekarang ini, mulai besarnya harapan dan kekhawatiran para orang tua terhadap masa depan putraputrinya. Anak sekarang ini sudah dianggap sebagai tumpuan harapan dan investasi masa depan yang paling berharga (Jain, 2012).

Berikut merupakan strategi yang dilakukan sekolah untuk menanamkan karakter kewirausahaan pada anak di sekolah. Adapun kegiatan yang paling banyak dilakukan guna menanamkan jiwa kewirausahaan pada anak ada tiga, diantaranya: Program Cooking class (Kelas memasak); program Outing class (melaksanakan kelas diluar ruangan); dan program Market day (kegiatan berjualan). Program kegaiatan tersebut semuanya membantu menanamkan jiwa kewirausahaan pada anak. Tidak ada larangan atau himbauan bahwa kegiatan ini wajib dilakukan semua atau hanya boleh dilakukan satu macam saja, tetapi program kegiatan ini bebas dilakukan kapan saja dan dengan intensitas yang tinggi maupun rendah disesuaikan dengan kondisi dan situasi lingkungan maupun anak sebagai pemeran utamanya (Saputra, 2015).

\section{Strategi Pengembangan Karakter Entrepreneurship di Sekolah Menengah}

Pada tingkat menengah atas strategi kegiatan akan dibuat lebih kompleks. SMK sebagai sekolah dengan keahlian khusus sudah lebih dulu mengimplementasikan strategi ini, bahkan pengintegrasian nilai kewirausahaan kedalam mata pelajaran sudah sejak awal di lakukan. Hal ini sejalan dengan yang dikemukakan Dir. Pembinaan SMK (Rasul, 2013) Semangat atau jiwa kewirausahaan di SMK dibentuk selain melalui mata pelajaran Kewirausahaan juga dikembangkan melalui kelas wirausaha (peserta didik mengembangkan kompetensi produkti fnya dengan mencoba menjalankan usaha kecil). Dengan demikian, kewirausahaan di SMK sebaiknya dilihat sebagai konsep yang lebih luas bukan hanya sesuatu yang berkaitan dengan bisnis atau hanya ditanamkan melalui 1 (satu) mata pelajaran dan kelas wirausaha, tetapi juga sebuah konsep yang dapat meningkatkan hasil belajar pe serta didik melalui semua ma ta pelajaran.

Sejalan dari pendapat diatas maka Leonardus Saiman (Afandi, 2019) merumuskan manfaat berwirausaha adalah sebagai berikut: 1 . Memberi peluang dan kebebasan untuk mengendalikan nasib sendiri. Memiliki usaha sendiri akan memberikaan kebebasan dan peluang bagi pebisnis untuk mencapai tujuan hidupnya. 2. Memberi peluang melakukan perubahan. Semakin banyak pebisnis yang memulai usahanya karena mereka dapat menangkap peluang untuk melakukan berbagai perubahan yang menurut mereka sangat penting. 3. Memberi peluang untuk mencapai potensi diri sepenuhnya. Banyak orang menyadari bahwa bekerja disuatu perusahaan sering kali membosankan, kurang menantang dan tidak ada daya tarik. 4. Memiliki peluang untuk meraih keuntugan seoptimal mugkin. Walaupun pada tahap awal uang bukan daya tarik utama bagi wirausahawan, keuntungan berwirausaha merupakan faktor motivasi yang penting untuk mendirikan usaha sendiri. 5. Memiliki peluang untuk berperan aktif dalam masyarakat dan mendapatkan pengakuan atas usahanya. Pengsaha kecil atau pemilik perusahaan kecil sering kali merupakan warga masyarakat yang paling dihormati dan paling dipercaya. Kesepakatan bisnis berdasarkan kepercayaan dan saling menghormati adalah ciri pengusaha kecil. 6. Memiliki peluang untuk melakukan sesuatu yang disukai dan dan menumbuhkan rasa senang dalam mengerjakannya. Hal yang dirasakan oleh pengusaha kecil atau pemilik perusahaan kecil adalah bahwa kegitan usaha mereka sesungguhnya bukanlah kerja. Kebanyakan wirausahawan yang berhasil memilih masuk dalam bisnis tertentu, sebab mereka tertrik dan menyukai pekerjaan tesebut. 
Dari pemahaman tentang strategi pengembangan karakter entrepreneurship di sekolah menengah diatas maka dapat di tarik kesimpulan bahwa agar lebih tertanam jiwa pada peserta didik, maka proses pelaksanaan pendidikan karakter, pendidikan kewirausahaan perlu dilakukan melalui perencanaan yang baik dan pendekatan pembelajaran yang efektif serta dilakukan secara bersama oleh semua warga sekolah, melalui pengintegrasian dalam mata pelajaran, muatan lokal maupun kegiatan-kegiatan dalam pengembangan diri. Dengan demikian, dalam waktu yang lama akan menjadi bagian yang tak terpisahkan dari budaya sekolah.

\section{KESIMPULAN}

Pendidikan karakter merupakan proses pembelajaran yang mengajarkan kebiasaan cara berpikir dan perilaku yang membantu individu untuk hidup dan bekerjasama sebagai keluarga, masyarakat. Karakter seorang anak dibangun melalui apa yang yang didengarkan, dilihat, dan dirasakan. Melalui seluruh indra yang manusia miliki inilah, akan diperoleh hasil pembelajaran yang kuat dan menjadi karakter anak di masa dewasa nanti. Sekolah atau lembaga pendidikan sebagai salah satu basis dalam pengembangan pendidikan karakter harus dapat mengimplementasikan pendidikan karakter pendekatan holistis, yaitu mengintegrasikan perkembangan karakter ke dalam setiap aspek kehidupan sekolah dengan menggunakan berbagai pendekatan. Disini dibutuhkan keseriusan seluruh komponen yang ada (kepala sekolah, guru, dan tenaga kependidikan) dan pemerintah. Kewirausahaan merupakan kemampuan kreatif dan inovatif yang dijadikan dasar, kiat dan sumber daya untuk mencari peluang menuju sukses. Membangun sikap kewirausahaan pada anak usia dini lebih kepada bagian membangun sifat dan karakter yang mandiri, bertanggungjawab melalui pendidikan wirausaha secara teoritis maupun praktis, serta contoh nyata karena pembentukan mental memerlukan waktu dan proses yang panjang. Bila anak terbiasa dengan dunia wirausaha sejak kecil, maka karakter inilah yang akan muncul kelak ketika anak dewasa.

\section{UCAPAN TERIMA KASIH}

Terimakasih kepada Ibu Dr. Rosmiati, M. Pd Selaku dosen pengampu Mata Kuliah Entrepreneurship dalam Pendidikan. Terima kasih kepada EDUKATIF: JURNAL ILMU PENDIDIKAN Research \& Learning in Education Universitas Pahlawan yang telah bersedia menerbitkan jurnal.

\section{DAFTAR PUSTAKA}

Afandi, Z. (2019, Juni). Strategi Pendidikan Entrepreneurship di Pesantren Al Mawaddah Kudus. BISNIS: Jurnal Bisnis dan Manajemen Islam, 7(1).

Agus, Burhanudin, \& Sultoni. (2018). Manajemen praktik kerja industri. Jurnal Administrasi dan Manajemen Pendidikan, 1(2).

Astuti, Suhandana, \& Dantes. (2012). Studi evaluasi efektifitas pelaksanaan praktik pengalaman lapangan (Prakerin) mahasiswa fakultas pendidikan olahraga dan kesehatan ikip pgri bali. E-journal Universitas Pendidikan Ganesha, 4.

Basuki. (2007). Analisis hubungan antara motivasi, pengetahuan kewirausahaan, dan kemandirian usaha terhadap kinerja pengusaha pada kawasan industri kecil di daerah pulogadung. Jurnal Usahawan, 2(10), $1-8$.

Dantes, \& Nyoman. (2012). Metode Penelitian. Yogyakarta: Andi.

Jain, M. $(2012,12)$. Social Entrepreneurship - Using Business Methods to Solve Sosial Problems: The Case of Kotwara, Decision. Social Entrepreneurship, 39(3).

Koesuma, D. (2010). Pendidikan Karakter: Strategi mendidika anak di Zaman Global. Jakarta: Grasindo.

Kurniawati. (2013). Pemberdayaan masyarakat di bidang usaha ekonomi (studi pada badan pemberdayaan masyarakat kota Mojokerto. Jurnal Administrasi Publik, 9(14), 1-4.

Madjid, A. (2011). Pendidikan Karakter Perspektif Islam. Bandung: Rosdakarya. 
5091 Strategi Pengembangan Karakter Entrepreneurship di Sekolah - Helty Asafri, Pitriyani, Rosmiati DOI: https://doi.org/10.31004/edukatif.v3i6.1588

Mukhibad, \& Susilowati. (2010). Studi evaluasi kompetensi mengajar mahasiswa Praktik pengalaman lapangun jurusan akuntansi universitas negeri Semarang. Lembaran ilmu kependidikan.

Mulyani, \& Jamilus. (2021). Pengembangan Pendidik Sebagai Sumber Daya Manusia di Sekolah Menengah Atas. EDUKATIF: JURNAL ILMU PENDIDIKAN, 3(4), 1170 - 1176.

Mulyani, E., \& dkk. (2010). Pengembangan Pendidikan Kewirausahaan. Jakarta: Badan Penelitian dan Pengembangan Kurikulum.

Qolb, S. K., \& Hamami, T. (2021, Universitas Pahlawan tuanku Tambusai Riau). Impelementasi Asas-asas Pengembangan Kurikulum terhadap Pengembangan Kurikulum Pendidikan Agama Islam. EDUKATIF: JURNAL ILMU PENDIDIKAN, 3(4), 1120 - 1132.

Rasul, D. (2013, Maret). Pelaksanaan Pendidikan Karakter, Ekonomi Kreatif, dan Kewirausahaan dalam Belajar Aktif di SMK. Jurnal Pendidikan dan Kebudayaan, 9(1).

Saputra, K. (2015). Pendidikan Berbasis Entrepreneurship. Yogyakarta: DIVA Press.

Saputro, E., Achmad,, N., \& Handayani, S. (2016). Identifikasi Faktor yang Mempengaruhi Sukses Wirausaha. Benefit, Jurnal Manajemen dan Bisnis, 1(1), 34-41.

Suharyadi, \& dkk. (2008). Kewirausahaan, Membangun Usaha Sukses Sejak Usia Muda. Jakarta: Salemba Empat.

Wijaya, Y. H., \& Harjanti, D. (2013). Enterpreneurial Leadership dan Hubungannya dengan Kinerja Bisnis pada Usaha Mikro Kecil di Wilayah Jawa Timur. AGORA, l(3).

Yanti , A., \& Mauliza, P. (2021, September). Sterategi Mengembangkan Jiwa Entrepreneur Kepada Siswa Sekolah Menegah Pertama (SMP) Vol. 9 No. 3 / September /2021. INFORMATIKA Manajemen Informatika Universitas Labuhanbatu, 9(3). 